\title{
Article
}

\section{Shall we forget human nature? Political anthropology and technics from Marx and Engels to Simondon}

\author{
Andrea Bardin ${ }^{\mathrm{a}, *}$ and Fabio Raimondi ${ }^{\mathrm{b}}$ \\ ${ }^{\mathrm{a}}$ Oxford Brookes University, Oxford OX3 0BP, UK. \\ abardin@brookes.ac.uk \\ ${ }^{\mathrm{b}}$ University of Udine, 33100 Udine, UD, Italy. \\ fabio.raimondi@uniud.it \\ *Corresponding author.
}

\begin{abstract}
Human nature is something of a taboo on the left wing of contemporary political theory and scarcely more than a commonsense assumption on its right wing. This article aims to expose the taboo and to challenge the assumption. There is no way, we argue, to defeat conservative political theory without delving into political anthropology. With this purpose in mind, our article analyses the writings of Marx and Engels, and Simondon's concepts of the transindividual and technics. It shows that Simondon's theory of technics allows new interpretations of many of the themes scattered in Marx's and Engels's works and helps to formulate a materialist political anthropology which entails a political project of liberating 'human nature' from labour.

Contemporary Political Theory (2023) 22, 24-45. https://doi.org/10.1057/s41296-02200546-9; advance online publication 7 February 2022
\end{abstract}

Keywords: political anthropology; transindividual; technics and labour; Marx; Engels; Simondon

The concept of human nature is something of a taboo on the left wing of contemporary political theory and scarcely more than a commonsense assumption on its right wing. This article aims to expose the taboo and challenge the assumption. Formulating human nature as a stable essence - in a spiritual or biological sense - means reducing it to an instrument by which politics can pursue a political realism that effectively naturalises the existing social hierarchy that is the expression of that supposed essence. And yet, turning human nature into an entirely social construction means dissolving it into interminable disputes incapable of implementing policies that can bring about real change in the existing conditions of exploitation. We reject both these conceptions as idealistic and seek to counter 
them by putting forward a materialist political anthropology that rejects every ontological separation between the human and the rest of nature. We intend to do this by drawing out the key elements of a political anthropology from the work of Marx and Engels and from Simondon's concepts of the 'transindividual' and 'technics'. More precisely, our article aims to extend the debate over the transindividual into the themes of biology and technics. Our proposal is ultimately centred on the question of technics, which, in our view, can save 'human nature' both from being reduced to an essence and from being dissolved into a mere social construct.

We begin by outlining the conception of human nature as praxis implicit in Marx's and Engels's political anthropology. The two considered the question of human nature only occasionally, in hints, brief statements and short reflections scattered haphazardly through their works. This is without doubt one of the reasons why political anthropology is a battleground for Marxists. Following Byron (2016), we can briefly identify three prevailing positions on Marx's and Engels's thoughts on human nature. The first (supported, for example, by Sayers) argues that Marx did believe in the existence of a human nature, albeit an entirely 'historic' one. In other words, human nature varies, depending on 'the different means of production', so it is therefore always historically contingent, hence no transhistorical feature of human nature can form the basis of political theory. A second group (including Althusser) argues that, although essentialism was a feature of the young Marx, he later rejected it, meaning that he ultimately determined that there was no such thing as human nature. A third position (supported by Geras and Callinicos, among others) claims that for Marx human nature was 'trans-historic', that is, 'the same in every moment of history', even if there is a lack of agreement on the characteristics of this human nature. Refuting Althusser's anti-humanism, Geras sees Marx's political anthropology as being grounded on a sociological theory of needs and does not appreciate Marx's and Engels's attempts to integrate their reflections on human nature with the scientific research of their time. Aside from the failure to consider Engels's contribution, what is remarkable about all three positions is the scarce attention paid to biological and technical aspects, and the joint considerations of these by Marx and Engels (see for example Fallot, 1971; Krader, 1975; Wallimann, 1981; Patterson, 2009).

We instead argue that the question of human nature is fundamental to Marx's and Engels's discourse and that an accurate analysis of their writings reveals that, despite their differences, they conceived it as both a historical and trans-historical phenomenon (that is, one capable of change while preserving the memory of the past), and as something impossible to comprehend without taking into account the technical ability of the human species. Our reading draws on Marx's and Engels's attempts to develop their reflections in accordance with the scientific research of their time, and our attempt to revive the Marxist debate on political anthropology is animated by specific attention to their efforts to combine the historical and trans- 
historical features of human nature. We neither intend to read Marx in the light of Engels's re-interpretation of his philosophy after his death, nor to keep their theories separate, as if a 'young' humanist Marx needed to be saved from an 'old' positivist Engels. Our task is rather to take seriously the interactions that reciprocally shaped their thoughts, as these show certain noteworthy, if sometimes unexpected, convergences, notably on scientific matters. ${ }^{1}$

As a result, we get to the core of Simondon's political anthropology, the concept of the transindividual. Our analysis is guided by a critical reading of other Marxist interpretations of the concept (Balibar, 1997; Combes, 2012; Read, 2016). Their scant interest in the themes of biology and technics as they relate to Simondon's theory of the transindividual probably lies in the fact that the issues in play have notoriously been monopolised by conservative and neoliberal political theories. The former denigrate technics by claiming the need to defend a human nature that it assumes to be invariable - in a biological or spiritual sense - from the risks of technological development. The latter defend it as an instrument for promoting a basically cosmopolitan human nature through the technocratic apparatus of capital conceived as intrinsically progressive and emancipatory. We agree that Simondon's concept of the transindividual is useful from a Marxist perspective because it is capable of freeing the notion of human nature from this theoretical monopoly, but we believe this can only be the case if one understands human nature as a field in which processes of biological subjectivation and technical invention take place, rather than as an essence.

With this background in place, we analyse more specifically Marx'a and Engels's understanding of the relationship between technics and labour, running from The German Ideology and Marx's subsequent works up to Engels's Dialectics of Nature. Hence, we consider Simondon's critique of the Marxist concept of alienation on the basis of his theory of technics. The concept of 'technics', for Simondon, includes technical knowledge and activity, as well as the tools and instruments (technology) produced and used through them, and it is distinct from labour as the social organisation of technical production in particular historical circumstances. While the former is the vector of a tendency towards opening up social systems, the latter is a mechanism of social normalisation and reproduction. Although the distinction between labour and technics is formulated by Simondon in explicitly anti-Marxist terms, it is nevertheless legitimate to use it to reinterpret the tensions within Marx's concept of labour and to assist with the formulation of our normative proposal: that the anti-capitalist struggle must aim to liberate technics from labour, or, rather, must organise the unleashing of the potential for invention and transformation inherent in technics by freeing it from the restrictive task of merely reproducing a specific form of social organisation maintained by labour. 


\section{Marx and Engels: Human Nature as Praxis}

Our starting point is the statement contained in the Sixth Thesis on Feuerbach, according to which 'the essence of man [menschliche Wesen] is no abstraction inherent in each single individual, but in its reality it is the ensemble of the social relations' (Marx, Theses on Feuerbach, in Marx and Engels, Collected Works, vol. 5, p. 4; hereafter CW). We will analyse in particular the nexus between 'essence of man', 'social relations' and 'ensemble' and show that at the core of their project is an understanding of human nature as a historical and natural praxis that includes but is not reducible to the relations of production.

Marx draws the intimate link between the 'species-being [Gattungswesen]' of men and their 'sociality' from the comparison of Hegel with Feuerbach (Basso, 2012, pp. 26-36). His interests in juridical matters initially limit his study of the 'essence of a "particular personality"' to its 'social quality', and 'not its beard, its blood, its abstract physical character', that is, to historical and not biological features (Marx, Contribution to the Critique of Hegel's Philosophy of Law, CW 3, p. 21). Human nature instead makes its appearance in the so-called Economic and Philosophic Manuscripts of 1844, where it is closely linked to alienation and property, as well as to the 'dissolution of the human's original unity with the earth' (Saito, 2017, pp. 25-62). The non-social component of 'human nature' that Marx refers to in that text as 'man's inorganic body' (Marx, Economic and Philosophic Manuscripts of $1844, \mathrm{CW} \mathrm{3,} \mathrm{p.} \mathrm{276),}{ }^{2}$ however, is far from trans-historical. It is in fact the result of the capitalist social relation that dissociates workers from the land and from possession of the means of production before legally establishing the opposing figures of the landowner and the free worker. Despite being an object of constant study by Marx and Engels, as attested by the former's Excerpts and by their correspondence, 'inorganic' nature appears in their publications only sporadically, at least until Anti-Dühring and Dialectics of Nature. ${ }^{3}$

In the Sixth Thesis, Marx still affirms that the essence of man is the historic 'ensemble' of social relations. Even the conscience, therefore, which for many (Hegel and Feuerbach, for example) constituted the essence of man, was to be understood as a 'social product' (Marx and Engels, German Ideology, CW 5, p. 44) and thus as historical (non-naturalistic) and non-pure (non-idealistic). This 'social' essence of man is not, however, the same as a 'universal human nature' (Marx, Leading Article in No. 179 of Kölnische Zeitung, CW 1, p. 191), which refers to the complete human being and, therefore, to the ensemble, defined by social relations, of his essence and of his 'inorganic body'. As we shall see, in some passages of the German Ideology, the link between essence and social relations - which always indicate an objective relationship, conscious or unconscious (Engels, Letter to Kautsky, 22 August 1884, CW 47, p. 186) - is more nuanced, but there is nevertheless no doubt that to understand human nature as an ensemble one must 
abandon all metaphysics of essence (including Feuerbach's), as well as all socioeconomic approaches, according to which the 'real essence of men' is their 'intercourse' (Hess, 1921, § 2). The latter fail to include the inorganic body, which is at once historic, given that it is a product of capitalist social relations, and transhistoric in some of its components.

In this sense, the Theses represent a scheme that allows us to recast the notion of ensemble through the concept of praxis, which reconnects the essence of man and the inorganic body by placing them in a relationship of continuity and reciprocity. In praxis, the 'circumstances' and 'the human activity of self-changing' are in a state of constant and reciprocal transformation (Marx, Theses on Feuerbach n. 3, CW 5, p. 4). ${ }^{4}$ Two consequences follow from this.

The first is a departure from the French debate on social relations, in which Bonald (a conservative), Saint-Simon (a socialist) and Guizot (a liberal) all granted the 'symbolic order' (i.e. ideology) the founding role in a society that functions, albeit in different ways, on the basis of 'communication' (Macherey, 1992, pp. 25-43). Whether the essence of man is conceived in a metaphysical or abstract way (Bonald and Feuerbach), or in an idealistic one (Guizot and Hegel), it remains ideological, or in other words, it is a discourse that may produce effects but has no scientific status. In relation to this context, the use of the term ensemble in the Sixth Thesis is crucial. If reality is praxis, a process of continuous interactions between the ensemble of social relations and nature (including human nature), its incessant transformation cannot be unified a priori, as Bonald, Saint-Simon and Guizot had argued. Praxis interpreted as an ensemble is, on the contrary, 'an indefinitely open multiplicity' and 'non-totalising a priori' (Macherey, 2008, pp. 141-142, $150-151),{ }^{5}$ the scientific understanding of which must be historical and natural, a project that Marx and Engels pursued for their whole lives.

The second consequence is the recovery of the reference to labour and technology, elements of praxis with their own rationale that form a non-Kantian practical reason irreducible to either formal logic or pure thought. Labour and technology in fact precede, make possible and accompany semantic language (Marx, Debates on the Freedom of the Press, CW 1, p. 174). In this purely materialist sense, even the truth, Marx said, 'is a practical question' (Marx, Theses on Feuerbach, n. 2, CW 5, p. 3). The concept of praxis thus makes it possible, on the one hand, to set labour against communication, a real transformation of the world against ideology, and, on the other hand, to anticipate the possible recomposition, through revolutionary action, of what the capitalistic social order had split apart.

The development of this perspective begins in The German Ideology, in which Marx and Engels write that 'the first premises of all human history' is the 'physical organisation' of individuals and of their 'relation to the rest of nature'. Without developing this point, they claim that 'all historical writing must set out from these natural bases and their modification in the course of history through the action of 
men'. The physical organisation of humans in fact conditions the organisation of their 'means of subsistence', which in turn contribute to the production of 'material life', to the extent that 'what individuals are coincides with the material conditions of their production' (Marx and Engels, German Ideology, CW 5, pp. 31-32).

At the heart of the argument are the productive forces that determine the division of labour and with it the forms of property, i.e. the relations of individuals (CW 5, p. 32). The expression 'productive forces' here defines, by approximation, the ensemble of productive capacities in an economic-social formation, in which labour power and the means of production - that is, labour (human and nonhuman), instruments or objects of work (technology) and nature (including human nature) - interact in mutual transformation. Marx and Engels argue that this ensemble is the 'real basis of what the philosophers have conceived as the 'substance' and 'essence of men [Wesen des Menschen]' (CW 5, p. 54). It is, in short, through labour and technology that a reciprocal action between productive forces and social relations (Marx, A Contribution to the Critique of Political Economy, CW 29, p. 263), but also between human and non-human nature, makes of history 'nothing but a continuous transformation of human nature' (Marx, The Poverty of Philosophy, CW 6, p. 192). Thus conceived as the historical premise of social relations, labour neither defines a 'trans-historical' essence that grounds them, nor can it ever be their harmonising factor. Labour is only a part of human essence conceived as praxis.

This complex and dynamic understanding of the essence of man as praxis not only stands in contrast to political realism, which assumes human nature to be biologically or metaphysically unchanging and present in all individuals (Raimondi, 2020), but also contradicts the socialists and Marxists who define it in terms of labour and entirely within the historical compass of the social relations of production. Marx's and Engels's insistence on praxis makes it clear that the essence of man is the 'iridescent' ensemble of social relations and the inorganic body of nature, which is not structured $a$ priori by any principle and therefore cannot be theorised and harmonised through communication, co-operation and solidarity, as explicated by Saint-Simon. Marx and Engels regard such attempts as ideological, and the irenic idea of the 'symbolic order' should be substituted by the concept of praxis conceived as a dynamic and conflictual field to be studied - historically and scientifically - in its inherent tensions and contradictions. Their 'essence of man', much like the concept of the transindividual theorised by Simondon, cannot simply be traced back to what is 'inherent in each single individual' (Sixth Thesis), but must be sought more broadly in the ensemble in which biology, technics and social relations play decisive and differentiated roles. 


\section{Simondon: Human Nature as Transindividual}

The problem we have set ourselves in analysing the texts of Marx and Engels, and notably their concept of praxis, is that of isolating the elements of a materialist political anthropology that does not make human nature either into a purely transhistoric essence or into a mere social construct. Balibar's seminal reading of Simondon's concept of the transindividual (Balibar, 1997) is the hallmark of all Marxist attempts to find points of contact between Simondon and Marx in that sense. This attempt, however, is limited by the fact that it does not sufficiently consider Simondon's reflections on biology and technics (Bardin and Rodriguez, 2018). What we are assuming here is that the direction indicated by Balibar is the right one, but that only a specific reflection on the role played by biology and technics in Simondon's concept of the transindividual can serve as the key to a genuinely Marxist materialist political anthropology.

In Balibar's interpretation, it is the use of the term ensemble in the Sixth Thesis that reveals Marx's materialist break from Hegel's approach. The term points to the 'incompleteness, horizontality and heterogeneity' of the social relations that constitute the rational and material essence - conceived in opposition to a substantial and ideal subjectivity - of the human being. Balibar, however, adds the criticism that in his materialist interpretation of history, Marx felt the need to base this essence on a specific factor, namely labour construed as the material basis of praxis (Balibar, 2007, 2012, pp. 27-30). It is in this context that Balibar turns to Simondon's concept of psychic and collective individuation, that is, the transindividual. This concept makes it possible to hold together the founding need and an open conception of social relations, both of which are present in Marx's thought, redirecting them towards the search for an (practical) essence of the human that is not limited to labour but also studies the system of processes in which something that might be classically defined as 'subjectivity' emerges (Balibar, 2018). Moving beyond Combes's Foucauldian analysis of the affective-emotive conditions of psychic and collective individuation in Simondon (Combes, 2012), Read extends the use of the term transindividual to the labour relationship in which the worker 'develops the faculties of their species' by producing political subjectivation (Read, 2014, pp. 210-211). On this issue, Read notes the inadequacy of Marx's analysis of labour, showing how it must be supplemented by the study of the collective composition of those 'preindividual' elements that form the preconditions for the transindividual individuation in which processes of subjectivation take place (Read, 2016). ${ }^{6}$ It is in this perspective that Simondon's thought can help to overcome the false alternative between the idea of an absolute human malleability and that of human nature as the permanent basis of social relations, thus supporting the shift towards a materialist political anthropology. However, this reflection requires an in-depth analysis of two crucial elements in the way in which Simondon constructs 
the concept of the transindividual, namely those of biological and technical individuation.

As elaborated by Simondon, the transindividual is rooted in a pre-social type of biological and technical processes, but without making biology and technics, the components of a supposed human nature to be either defended or realised. Balibar captures this aspect well when he states that Simondon's philosophy allows us to formulate a political anthropology in terms of the 'relationship between individuation and [psychosocial] individualisation' (Balibar, 1997, p. 36). The problem with this formula is that it can lead to the implicit acceptance of an ontological distinction between what is singular and historical in human psychosocial individualisations and the biological and technical individuations which are their precondition, but which are not investigated in their specific historicity. Both the biological and the technical individuations are thus implicitly assumed to be ahistorical and apolitical, unless they can be politicised a posteriori, and Simondon's entire philosophy of individuation is understood only starting from the concept of the transindividual, which is interpreted as an essentially political element, despite the fact that its dependence on pre-historical and pre-political conditions of possibility is recognised.

Being de-historicised in this way, the biological dimension of the human is considered to be genuinely human only within social relations, and its technical dimension, implicitly de-politicised, is fully understood within the relations of production (as happens in many interpretations of Marx and, often, also in Marx himself). In short, human nature is constantly defined by the horizon of the social relations of production, understood in this way as a totality rather than as an ensemble. The consequence of this approach is that a subjectivity and a human nature that precede (both chronologically and logically) the different political forms in which human sociality historically occurs are inconceivable.

It is deceptive but also revealing that in Simondon's texts the term 'subject' provides an ambivalent definition of both the individuation of an organism in general and the individuation from which the 'subject-being [l'être sujet]' emerges on the transindividual level (Simondon, 2005 [1958], p. 310; hereafter Individuation). Subjectivation is studied by Simondon as a complex process that takes place on three different orders of magnitude, three phases, each of which develops in turn on its own timescale, although the term subject is used on two different levels in different sections of Individuation. The section relating to biological individuation refers to the individuation ('ontogenesis') of an organism-subject in relation to its external environment and based on its phylogenetic legacy. ${ }^{7}$ The section relating to psychic and collective individuation instead refers to the series of individualisations from which the subject emerges as a 'more or less consistent system of three subsequent phases: preindividual, individuated and transindividual' (Individuation, p. 310). In fact, the term 'subject' thus covers all the processes of individualisation, that is, 'every thought, every conceptual discovery, every emotional upsurge', since 
these are a 'partial but faithful' repetition and transformation of preindividual potentials still present in the biological subject following its 'absolute' individuation as an organism (Individuation, p. 264).

This ambiguity in the use of the term subject stems from the attempt to describe two equally essential aspects of the same process through which an organism continues its individuation within a social dimension that is essential to it, but which nevertheless does not exhaust its historicity (since biological evolution has its own historicity which, despite taking place on another timescale, is intertwined with the specifically psychosocial one). ${ }^{8}$ In this sense, transindividual individuation must be understood as a complex process in which different phases (or timescales) coexist in the single individual that can be made compatible but are never in any $a$ priori harmony. Biological individuation, in this sense, is a necessary condition of the subsequent individualisations, and it already produces a certain level of subjectivation. For this reason, the concept of the transindividual is used by Simondon with reference to every form of complex organic life and is not exclusive to homosapiens. Neither is it one of the species' permanent characteristics. ${ }^{9}$ The difference between humans and animals, rather than being substantial, therefore appears to be one of the intensity dependent in particular on the mediation carried out by technics, that is the activity of humans on their environment and on themselves, mediated by the production and use of technical objects (Simondon, 2015, pp. 17-18). Thus conceived, technics is a very peculiar element of psychosocial relations, because it is decisively intertwined with the evolutionary history of the human species.

In Simondon's terms, the human subject that enters the relational composition of the transindividual field does so on a 'bio-technical' basis rather than on a merely biological or social one. As we will see more clearly below, transindividual individuation relies on the existence of a milieu of technical and symbolic objects which, while partially independent from their producers, not only mediate the social relationship between different individuals, but also that between individuals and the natural world in which they live and in which they are transformed, biologically, psychically and socially. In short, human bio-technical individuation is a precondition for any further psychic and collective individualisation of the human subject. In this sense, for Simondon, technical activity is already in itself collective (Simondon, 1989 [1958], p. 245; hereafter Du mode).

This does not mean, of course, that the emergence of a sociality is not an integral part of the human and, given the evolutionary history of the species, also a determining factor in its biological and technical development. It does, however, mean that it is possible to speak of a human nature regardless of the different forms of psychic and collective individuation - that is, in Simondon's terms, without individualisation - but not without referring to the bio-technical individuation that is its precondition. Without biology, of course, but in fact also without technical activity and its products, neither homosapiens - who come from an evolutionary 
path in which technics has played a biologically determining role - nor imagination, language and the complex of social relations that make up the fully human praxis that forms the object of political analysis, would ever emerge from a natural history that they continue under another form, even if sometimes in radical discontinuity with it. Our thesis is that this material and historical essence of human nature defines the ontological core of the transindividual and must therefore be the epistemological presupposition of a materialist political theory. Taking this into consideration, we will once again confront the texts of Marx and Engels.

\section{Labour and Technics in Marx and Engels}

We have seen that Marx and Engels assign to praxis the task of reconstructing the ensemble of social relations and of the inorganic body in a new way. Simondon's analysis of the transindividual then demonstrates the need to address the issues of biology and technics in order to define a political anthropology that is neither reductionist nor dismissive of human nature thus conceived. In this section, we examine the terms in which Marx and Engels address the question of technics as a defining aspect of human nature, and we disentangle it from the concept of labour. Marx and Engels never explicitly differentiate the concepts of labour and technics. On the contrary, they usually include technology within their analysis of the concept of labour, and they rarely thematise the inventiveness proper to human technical activity independently of the historical relations of production within which labour is always inscribed. We believe, however, that some sort of conceptual distinction between labour and technics is implicit in many of their arguments, as we shall explore now.

History exists because humans always 'produce their life ... in a certain way', in accordance with their physical organisation, the different degrees of development of technics and knowledge, and the continuous redefinition of their needs. The resultant transformations depend on the potentialities of nature, both human and non-human, against which the efficacy of technics is measured and which the sciences attempt to understand. Human physical organisation is the pivot of praxis, since it is in relation to it that humans relate to the 'rest of nature' in order to construct 'their means of subsistence' and determine their specific 'mode of production', which is more than 'the reproduction of the physical existence of the individuals', but also 'a definite form of activity ... a definite form of expressing their life, a definite mode of life' (Marx and Engels, German Ideology, CW 5, p. 43n.* and p. 31).

This 'socially determined production' is for Marx and Engels 'the point of departure' (Marx, Economic Manuscripts of 1857-1858, CW 28, p. 17) of scientific and political debate because it always involves historically defined organisations that make specific connections between the socio-political structure and production 
by individuals 'as they actually are, i.e. as they act, produce materially, and hence as they work under definite material limits, presuppositions and conditions independent of their will' (Marx and Engels, German Ideology, CW 5, pp. 35-36). Constraints are legacies of the past, both natural (modified or not by human activity) and social, a term that 'denotes the co-operation of several individuals, no matter under what conditions, in what manner and to what end'. But what counts is that 'a certain mode of production, or industrial stage, is always combined with a certain mode of co-operation, or social stage, and this mode of co-operation is itself a "productive force", (CW 5, p. 43). ${ }^{10}$ This is an incessant praxis. The satisfaction of a need and the instruments used lead to new needs (CW 5, p. 42) because they not only modify the objective conditions, but also the producers who develop 'new powers and new ideas, new modes of intercourse, new needs, and new speech' (Marx, Economic Manuscripts of 1857-1858, CW 28, p. 418).

Marx explores some aspects of this view in Capital when he studies 'the evolution of the economic formation of society ... as a process of natural history' (Marx, Capital, vol. I, CW 35, p. 10) by analysing some of its components. The first of these is labour, which Marx identifies with 'labour power in use', to be understood as 'the aggregate of those mental and physical capabilities existing in the physical form, the living personality, of a human being, capabilities, which he exercises whenever he produces use value of any kind'. Labour is 'a process between man and nature, a process by which man, through his own action, mediates, regulates, and controls the metabolism between himself and nature'. In this way, 'man opposes himself to nature as one of her own forces ... By thus acting on the external world and changing it, he at same time changes his own nature' (CW 35, pp. 177, 187).

The second component is the instrument of labour, which 'is a thing or a complex of things, which the labourer interposes between himself and the object of his labour': whether this be an element of nature, which becomes 'one of the organs of his activity', or a human artefact, which leads to the definition of man as 'a toolmaking animal'. Such instruments, that is technology, 'are also indicators of the social relations under which labour is carried on', because they involve the objective conditions 'necessary for carrying on the labour process', which include the 'soil', but also 'workshops, canals, roads, and so forth'. Hence 'technology reveals the active relation of man to nature, the immediate process of production of his life, and thereby it also lays bare the mode of production of the social relations of his life, and of the mental conceptions that flow from them' (CW 35, pp. 188-190, 375 n. 2). In a similar vein, Engels will specify that economic relations include 'the entire technology of production and transport' and its 'geographical basis ... the external environment', which contributes to determine 'the manner of exchange, likewise the distribution of products and ... also the division into classes, hence the relations of rulers and subjects, and hence the state, politics, the law, etc.' (Engels to Borgius, 25 January 1894, CW 50, pp. 264-265). 
Both these statements point, in our view, to the need for a natural history of the productive organs of social man expounded by Marx in analogy with the 'natural technology' of which Darwin had spoken in On the Origin of Species.

Finally, the third component is 'metabolism', whose necessary conditions are labour and technology. Metabolism is a concept that includes natural and social aspects on which Marx worked intermittently between the end of the 1850s and the 1880 Marginal Notes on Adolf Wagner's Lehrbuch der politischen Ökonomie (CW 24 , pp. 531-559, especially p. 553). This is a rather stratified concept that aims to account for the circular movement through which nutritional elements are refined, assimilated through human labour, and finally 'expelled' in the form of deceit. The cycle continues at the social level with the necessity for the mode of production to reintegrate its own natural and social conditions of possibility, that is, the labour force and natural resources (Saito, 2017, pp. 63-175). In Marx's argument, the concept of metabolism helps to identify the social as well ecological problem created by capitalism: 'capitalist production ... disturbs the metabolism between man and the soil' by standing in the way of the reintegration of the physicalchemical elements consumed by mankind and, at the same time, 'imperiously calls' this reintegration 'a regulating law of social production' (CW 35, pp. 194, 506-507). Pursuing this objective requires, and this is Marx's point, that the means of capitalist production be abandoned, and 'the associated producers, rationally regulate their metabolism with nature', including inorganic and human nature (Marx, Capital, vol. III, CW 37, pp. 807, 802).

These three elements demonstrate that labour as a form of social reproduction does not fully coincide with praxis understood as a natural power; that technical objects are forces that transform the world and themselves through an unceasing exchange between human beings and nature; and that such a metabolism, threatened by capital, is not an original mythical state of equilibrium, but a praxis able to rationally 'mediate, regulate and control' the reciprocity between human beings and nature. The metabolism, in fact, is a circular process that never repeats itself identically but which, in order to continue, requires humanity's active participation in the relationship of co-evolution that it maintains, through labour, with nature.

In our view, Engels's The Part Played by Labour in the Transition from Ape to Man should be read in relation to these claims and this problem. The text was part of a project on which, in agreement with Marx, he worked for some time, and which we believe can provide an interpretative scheme for certain premises of Marx's own discourse. Labour, together with nature, is 'the source of all wealth', but, above all, it is 'the prime basic condition for all human existence' to the point that 'labour created man himself'. But if labour 'begins with the making of tools', then technical activity is the 'base' of humanity. Here Engels is writing about labour as praxis, as a technical activity that requires cognitive skills, free from the economic-juridical forms that enclose it in relations of production, including 
capitalist ones. Thus conceived, as a technical activity, labour specifically characterises human nature as the open praxis from which it emerges and which it contributes to transform. The human hand, for example, 'is not only the organ of labour, it is also the product of labour'. It was with the development of this labour that human beings 'had something to say to each other': language was born 'from and in the process of labour'. The conclusion is clear: 'first labour, after it and then, with it, speech'; language is a tool among several others, from which developed the consciousness that then gave 'both labour and speech an ever-renewed impulse to further development' (Engels, Dialectics of Nature, CW 25, pp. 452-457).

At least two consequences follow from Engels's argument. The first is that 'animals change the environment by their activities in the same way, even if not to the same extent, as man does, and these changes '... in turn react upon and change those who made them'. The second is that 'the animal merely uses its environment, and brings about changes in it simply by its presence; man by his changes makes it serve his ends, masters it ... and once again it is labour that brings about this distinction'. This domination, however, is not the same as that of 'a conqueror over a foreign people' or that of 'someone standing outside nature', because we 'belong to nature, and exist in its midst'. In other words, it envelops us, 'and all our mastery of it consists in the fact that we have the advantage over all other creatures of being able to learn its laws and apply them correctly': and the more we learn that 'men not only feel but also know their oneness with nature', the more 'the senseless and unnatural idea of a contrast between mind and matter, man and nature, soul and body' becomes 'impossible' (CW 25, pp. 459-461). This is an awareness that Marxism rarely arrived at, as it was too often impeded by its anthropocentric commitments.

The inclusion of technics in the concept of praxis instead allows Marx and Engels to overcome the schism between humans and nature produced by capital, that is, to see human nature as the ensemble of its essence and its inorganic body. Thus conceived, praxis defines the historically evolving relationship between the human bodies and needs, and the means of production, of which techniques and the sciences are a part. In this sense praxis cannot be reduced to labour, which is merely one aspect of it, as it also includes a pre-social form of activity not only aimed at production or social reproduction but also at invention and self-change. The tension inhabiting the ideas of praxis and labour is made visible, as we are going to explain, by Simondon's critique of Marx's concepts of labour and alienation.

\section{Labour, Technics and Alienation in Simondon}

Simondon theorises the relationship between labour and technics as an opposition between collective activity involved in the reproduction of the status quo, and 
collective activity of invention challenging the established forms of production and social norms. He does so by explicitly formulating his concept of technics as a key component of transindividual relations in contrast to the understanding of labour as the essence of man, which he attributes to Marx. Notwithstanding the fact that Simondon's conceptual distinction between labour and technics is formulated in explicitly anti-Marxist terms, we believe that it can be used to reconsider the tensions within the Marxist concept of labour (Toscano, 2007, pp. 203-204), to clarify some of its ambiguities and to resolve, from the perspective of a materialist political anthropology, the misunderstanding that leads to the identification of labour with wage labour.

For Simondon, organising and dividing labour on the basis of the shared needs of a group is the act that constitutes an essentially biological 'community' (Individuation, p. 512): in other words, one in which individuals of the same species, and not only homo sapiens, place themselves in a purposeful relationship with one another and with their environment. The rigidly structured 'interindividual' relationships that characterise the 'working group', whether animal or human, are only the prerequisites for that psychic and collective 'second individuation', the naming of which, according to Simondon, inevitably calls for the introduction of the term 'transindividual'. The transindividual exists 'above the biological, biological-social and interindividual relations', for it exceeds the organisation of labour and facilitates the exploitation of nature. It follows that labour cannot define the essence of man nor can it 'be integrated into an anthropology' (Individuation, pp. 301-302). Making labour the essence of man is precisely the reductive and ideological operation which, based on the 1844 Manuscripts, he attributes to Marx. In the opinion of Simondon, Marx had incorrectly based his anthropology on 'a naturalised definition of labour' ( $D u$ mode, p. 241) drawn from a historically determined fact, namely the fundamental role played by alienated wage labour in the capitalist society of nineteenth-century Europe (Du mode, pp. 117-118 and Individuation, p. 302). In reality, the alienation described by Marx in relation to the method of capitalist production is for Simondon only a specific instance of a more general (and ontological) alienation that relates to labour as a whole (Bontems, 2013).

In Simondon's formulation, labour is alienating because it directs the group towards the production and use of technologies in accordance with established social norms and ends (capitalist or otherwise); that is, towards labour that is useful to a given social order and is therefore closed to the invention of new norms and ends (Individuation, p. 308). In short, in Simondon's language, (inventive) transindividual technical activity is alienated in (reproductive) 'interindividual' labour activity. In this sense labour, which depends on and contributes to the reproduction of hierarchical norms and relationships among the individuals forming a group, is radically opposed to the genuinely collective activity conveyed by technics, that is, the capacity to modify relations of production within a group 
through the invention of technical objects. Whereas 'the labour community brings into relation only individuated beings', in the collective 'it is not the individual who invents, but the subject, larger than the individual, richer than it'. In short, for Simondon, the term 'labour' defines an activity that is fundamentally alienated and does not become so as it is subsumed by a particular mode of production. In this sense, he speaks of 'a pre-capitalist alienation essential to labour as such' ( $D u$ mode, p. 248).

In line with these premises, the conclusion of $\mathrm{Du}$ mode outlines a pedagogicalpolitical project aimed at releasing the socially inventive potential of technics from its epistemological and ontological reduction to labour. This provides an alternative both to the project of integration and normalisation implicit in the psychosociological approach and to the Marxist dream of emancipatory revolution: 'the real way to reduce alienation is not situated within the social domain (with the community of labour and of class), nor in the dominion of interindividual relations that social psychology habitually considers, but on the level of the transindividual collective'. In Simondon's perspective, in fact, only technical activity, and not the labour activity that is the source of alienation, can be considered 'an inter-human relationship which is the model of transindividuality' (Du mode, p. 248).

Interpreted through its technical roots, the transindividual thus qualifies human inventiveness, both technical and normative, implying two simultaneous factors of complexity. On the one hand, as has been said above, the transindividual explains the internal complexity of a process of subjectivation in which human individuals are constituted in a technical dimension that is embedded in the biological evolution of the bio-technical species to which they belong. On the other hand, the transindividual explains the complexity of the relations emerging among the 'techno-symbolic milieu' that individuals inhabit and that their groups constantly modify and recreate (Bardin, 2015, pp. 158-161). Technical and symbolic objects and processes in fact nurture a milieu in constant interaction with its own biological and technical premises. Simondon sometimes uses the word culture to refer to this constantly transforming milieu populated by technical and symbolic objects in which the processes of individuation that as a whole respond to the concept of the transindividual take place. ${ }^{11}$

This techno-symbolic milieu is theorised by Simondon through the lens of LeroiGourhan's early work. The French paleoanthropologist observes in the technical relationship between a human group and its natural environment a factor of normative invention and therefore the root of a tendency to openness towards other groups and change. Every technical object (tool, instrument or machine) is invented, constructed, developed and functioning in a complementary relationship with the laws of nature, that is, with the physiology of human bodies and the variations of the natural environment, which are to a large degree independent from the symbolism and practices that govern the group. Conversely, the production, processing and exchange of symbolic objects (words, images, myths etc.) are not 
directly subjected to the limits of the laws of nature but rather to the normative ones of mental, social and political processes unique to each group. For this reason, although the symbolic life of a group tends to look inwards towards the reproduction of its internal relationships, the 'materialised layer' of technical objects which 'envelopes' human groups conveys a tendency to openness and universalisation that can never be reduced to the symbolic code developed within each human group (Leroi-Gourhan, 1945, p. 361).

In this sense, for Simondon technics tends to facilitate the construction of new relations both within a group and among different social groups, and, on this basis, the technical object can become both the 'medium and the symbol of a transindividual relationship' ( $D u$ mode, p. 252) that punctures and overcomes the self-referential normativity consolidated in the imagination of members of a group through mythologies, rituals and other forms of symbolic exchange. Indeed, every transindividual individuation occurs within the framework of a disharmonious relationship between three sorts of factors: (a) biological patterns that vary in the long and very long term of natural history, but which tend to repeat themselves in the short term; (b) the incredibly quick accumulation of technical innovations, whose functioning and duration largely depends on their relation to the natural milieu; (c) the symbolic order that attempts to integrate both into an institutional present, the existence of which can, however, become more and more selfreferential and detached from biological and technical processes.

Symbolic activity, including language, therefore works, so to speak, on an intermediate timescale: that of social and political normativity, which, however, must always react and deal with biological and technical processes that function on the basis of mainly non-symbolic criteria and are therefore always able to challenge its tendency towards insularity. Perceiving human nature as transindividual thus means conceiving it as a field rather than as an essence, a field which is formed by a series of biological and technical processes and at the same time by symbolic processes that attempt to intercept them, normalise them and direct them towards social reproduction. This attempt to capture symbolically non-symbolic processes is nevertheless unending and constantly called into question by organic and technical factors that together comprise the conditions of existence and the critical elements of the symbolic order itself (Individuation, p. 508).

Against this background, it is possible to explain the opposing regulatory function performed by labour and technics with respect to symbolic production, which the former helps to reproduce while the latter tends to modify. Put differently, the activity of labour is limited to reproducing norms directed towards the exploitation of the environment according to norms decided within the group, and it therefore tends to be conservative. Instead, technical activity seeks to introduce norms that put the group in relation to other groups and changes in the environment, and therefore tends to be innovative. In this sense, Simondon speaks of 'technicity' when defining the technical inventiveness that unites the human 
'mode of existence' and that of the same technical objects which mediate the relationship between social groups and between them and the world around them (Individuation, p. 527). Technical objects are integral part of the ontogeny of the human species in its relationship with the environment, and convey, resume and relaunch on the scale of transindividual individuation the inventive force from which they emerged.

In short, in the language of Simondon, only technicity is to be considered ontologically oriented towards change, while labour is intrinsically oriented towards the reproduction of existing economic and social relationships. Understood in this way, Simondon's critique of labour can thus convey a praxis of recovery and liberation of human inventiveness whose priority and urgency Marx was unable to discern because he was hindered by a humanistic culture that examines technics through the lens of the 'paradigm of labour' (Individuation, p. 303). In parallel, on the epistemological level, technicity is the factor whose analysis must precede the study both of labour, conceived as a mere regressive modality of technics, as well as the capitalist economy, construed as a means of subjugating technical inventiveness to the historically determined organisation of social relations that emerged in the nineteenth century and still continues in other forms. Therefore, the problem of labour is not resolved politically by liberating it from the capitalist relations of production, but with the liberation of technical inventiveness from labour.

The conceptual distinction between technics and labour propounded by Simondon may not do justice to the complexity of Marx's reflection on the concept of labour. However, it allows us to reread the tensions within it from the perspective of a materialist political anthropology without limiting the scope of its criticism to the capitalist mode of production, but also without in any way compromising the trans-historic recovery of an essence of man. According to Simondon, Marx attributes the cause of alienation to the capitalist mode of production alone because he does not grasp the difference between labour and technics. The first part of this observation is substantially correct, the second less so. In fact, Marx's and Engels's texts clearly show that they understood the inventive and transformative side of technics within the very concept of labour. Their concept of labour includes both the activity that takes place within a productive regime designed to preserve and reproduce it ('labour' for Simondon) and one which works to abolish it ('technicity' for Simondon). The latter, for Marx and Engels, is an aspect of labour, whose clearest example is precisely the sum of inventions and knowledge that enabled the capitalistic mode of production to assert itself over previous forms.

This shows that for Marx, Engels and Simondon, the root of alienation is principally technical: for Marx and Engels, it is the result of the expropriation of the technical tools by a part of humanity, while for Simondon, it is the outcome of the control exercised over human technicity by harnessing it for the normalised 
repetition of work cycles. For Marx and Engels, political-juridical instruments (like the enclosures) were the means of expropriating the peasants' control over their tools of collective production by forcing them to sell their labour power and become worker-atoms able to transform the world and therefore themselves only by using tools belonging to others. For Simondon, the slavery of the technical object reduced to an instrument of power is in itself a submission of the human inventiveness crystallised in it for purposes established by the social forms that from time to time dominate ( $D u$ mode, pp. 9-11).

\section{Conclusion}

A materialist political anthropology drawn from Marx, Engels and Simondon invites us to deal with technics - that is technical activity as well as the technical objects it produces - as something crucially embedded in human nature and as a specifically political problem. This approach sets itself against the technocratic dream of making technology something that finally relieves politics of the burden of decision-making, as well as standing against the fascist dream of establishing an exclusively instrumental relationship with technology based on a mythical purity of politics.

Engaging in politics in a materialist sense in this context means outlining a project of emancipating human nature conceived as praxis, including technicalscientific practices, from subsumption in capital. If technics is an integral part of the metabolism with nature which, mediated by social relations, makes humans what they are, the capitalist mode of production requires that some human beings be deprived of control over the technical inventiveness (technicity) inherent in their working activity or that this be surrendered to other objectives (such as those of profit, for instance). For this reason, however, developed, the capitalist machine 'does not free the labourer from work' (Marx, Capital, vol. I, CW 35, p. 426). On the contrary, alienated humans are economically impoverished because they are not free to know and transform the world (including themselves), and, through labour, they are subject to norms and purposes established by the owners of the means of production that govern the power to do so.

It is therefore in technics, removed from the labour that is a mere reproduction of the existing relations of power, that humans can grasp their own uniqueness as natural beings without projecting it onto a deceptive and self-destructive transcendence, as idealistic humanism does when it searches for an essence of the human on the level of symbolic relations and language. In the perspective offered by a materialist political anthropology centred on technics, 'it is not a matter of freeing labour but of abolishing it' (Marx and Engels, German Ideology, CW 5, p. 205). Liberation from labour can only occur with the liberation of the technical potentialities inherent in human nature, the becoming of which can be 
captured by neither capitalist nor socialist productivism, nor by the innumerable bourgeois philosophies of spirit.

\section{Acknowledgements}

We are greatly indebted to Matthew Armistead, Michele Basso, Filippo Del Lucchese and Mark Neocleous for their extensive work on earlier drafts of the manuscript. We especially thank Luca Basso and all the students and colleagues in the Marx Seminar at the University of Padua, where we first presented our research, receiving insightful critiques and suggestions. The anonymous reviewers and CPT editors were also very helpful in their detailed comments, which undoubtedly improved the article greatly.

Open Access This article is licensed under a Creative Commons Attribution 4.0 International License, which permits use, sharing, adaptation, distribution and reproduction in any medium or format, as long as you give appropriate credit to the original author(s) and the source, provide a link to the Creative Commons licence, and indicate if changes were made. The images or other third party material in this article are included in the article's Creative Commons licence, unless indicated otherwise in a credit line to the material. If material is not included in the article's Creative Commons licence and your intended use is not permitted by statutory regulation or exceeds the permitted use, you will need to obtain permission directly from the copyright holder. To view a copy of this licence, visit http:// creativecommons.org/licenses/by/4.0/.

\section{About the Author}

Andrea Bardin is a Senior Lecturer in Politics at Oxford Brookes University. He works on the relationship between science and political thought from early modernity to the present. He has written extensively on Thomas Hobbes and Gilbert Simondon. He is the author of Epistemology and Political Philosophy in Gilbert Simondon: Individuation, Technics, Social Systems published by Springer.

Fabio Raimondi teaches history of political thought at the University of Udine. He works on the interconnections between political theory, the natural sciences and political philosophy, with special focus on early modernity and Marxism. He is the author of several books and articles on Giordano Bruno, Niccolò Machiavelli, Karl Marx and Louis Althusser. His recent publications include the book Constituting Freedom: Machiavelli and Florence for Oxford University Press. 


\section{Notes}

1. Their epistolary displays an impressive variety of scientific topics discussed over thirty years, from the beginning of the 1850s until Marx's death, showing how the two often moved from bitter disagreements to shared views, such as in their attitude towards Darwin and Trémaux (Raimondi, 2014). We are endorsing here Timpanaro's claim that 'the anti-Engels operation ... ends by seriously compromising materialism itself' and 'those who have embarked on a "Marxism without Engels" have arrived, coherently enough, at a "Marxism without Marx", (Timpanaro, 1975, pp. 76, 132). Tosel (1995) makes a similar point. The debate on the Marx-Engels theoretical relationship is of course far from closed and has recently been revived by Saito (2021). We have provided our own translations of Marx's, Engels's and Simondon's works on the basis of the original texts in German or French, or modified the translations to which we refer, according to our interpretation.

2. On the notion of an 'inorganic body', see Foster and Burkett (2016, pp. 57-88).

3. 'As shown by the correspondence '... Marx followed closely the germination of the Dialectics of Nature; he read all of the Anti-Dühring before its publication and collaborated on it by writing a chapter for it' (Timpanaro, 1975, p. 77). See in particular the letters 14 July 1858 (CW 40, pp. 326-327) and 30 May 1873 (CW 44, pp. 500, 503).

4. It is in this sense that 'all social life is essentially practical' (Marx, Theses on Feuerbach n. 8, CW 5, p. 5).

5. Macherey discriminates between ensemble and totality, building on Balibar (2007, p. 30).

6. Language is interpreted as 'preindividual' by Virno (2003).

7. The subject is 'more than individual, individual and nature ... and at the same time both phases of being' (Individuation, p. 307).

8. On Simondon's concept of historicity spanning all material processes, including those studied by the hard sciences, see Bardin (2015, p. 210).

9. Transindividual individuation can 'normally or exceptionally' take place (Individuation, p. 165) in both animal and human groups (Individuation, p. 301).

10. 'Industrial' (from the Latin industria) refers here to all sorts of technicalproductive activity.

11. On the 'technical' nature of culture itself, see Simondon (2015). On the technical 'exteriorisation' of memory as the precondition of transindividual individuation, see Stiegler (1998).

\section{References}

Balibar, É. (1997) Spinoza: from individuality to transindividuality. Mededelingen Vanwege Het Spinozahuis 71: 3-36. 
Balibar, É. (2007) The Philosophy of Marx. London-New York: Verso.

Balibar, É. (2012) From philosophical anthropology to social ontology and back: What to do with Marx's sixth thesis on Feuerbach? Postmodern Culture 22(3).

Balibar, É. (2018) Philosophies of the transindividual: Spinoza, Marx, Freud. Australasian Philosophical Review 2(1): 5-25.

Bardin, A. (2015) Epistemology and Political Philosophy in Gilbert Simondon: Individuation, Technics, Social Systems. Dordrecht: Springer.

Bardin, A. and Rodriguez, P. (2018) A Vindication of Simondon's political anthropology: Response to Balibar. Australasian Philosophical Review 2(1): 54-61.

Basso, L. (2012) Marx and Singularity. From the Early Writings to the Grundrisse. Leiden-Boston: Brill.

Bontems, V. (2013) Esclaves et machines, même combat! L'aliénation selon Marx et Simondon. Cahiers Simondon 5: 9-24.

Byron, C. (2016) Essence and alienation: Marx theory of human nature. Science and Society 80(3): 375-394.

Combes, M. (2012) Gilbert Simondon and the Philosophy of the Transindividual. Cambridge: The MIT Press.

Fallot, J. (1971) Marx et le machinisme. Paris: Cujas.

Foster, J.B. and Burkett, P. (2016) Marx and the Earth. An Anti-Critique. Leiden-Boston: Brill.

Hess, M. (1921) The Essence of Money, https://www.marxists.org/archive/hess/1845/essence-money, accessed 22 January 2021.

Krader, L. (1975) Marxist anthropology: Principles and contradictions: New perspectives in the science of man: Part I: Society, individual and person. International Review of Social History 20(2): 236-272. Part II: Abstract and Concrete Labour. Ibid. 20(3): 424-449.

Leroi-Gourhan, A. (1945) Evolution et techniques II. Milieu et techniques. Paris: Albin Michel.

Macherey, P. (1992) Aux sources des rapports sociaux: Bonald, Saint-Simon, Guizot. Genèses 9: 25-43.

Macherey, P. (2008) Marx 1845. Les 'Thèses' sur Feuerbach. Paris: Éditions Amsterdam.

Marx, K. and Engels, F. Collected Works. Moscow-New York-London: Progress Publishers-International Publishers-Lawrence \& Wishart.

Patterson. Th. C. (2009) Karl Marx, Anthropologist. Oxford-New York: Berg.

Raimondi, F. (2014) Marx, Darwin e la 'storia critica della tecnologia'. Società Italiana di Filosofia Politica http://www.sifp.it/articoli-libri-e-interviste-articles-books-and-interviews/marx-darwin-ela-storia-critica-della-tecnologia.

Raimondi, F. (2020) Note su natura umana, scienze e realismo politico. Scienza \& Politica 12: 153-173. Read, J. (2014) La produzione della soggettività: dal transindividuale al comune. In: É. Balibar and V. Morfino (eds.) Il transindividuale. Soggetti, relazioni, mutazioni. Milan: Mimesis, pp. 207-230.

Read, J. (2016) The Politics of Transindividuality. Leiden-Boston: Brill.

Saito, K. (2017) Karl Marx's Ecosocialism. Capital, Nature, and the Unfinished Critique of Political Economy. New York: Monthly Review Press.

Saito, K. (ed.) (2021) Reexamining Engels's Legacy in the 21st Century. Palgrave-Macmillan.

Simondon, G. (1989 [1958]) Du mode d'existence des objets techniques. Paris: Aubier (Of the Mode of Existence of Technical Objects. Minneapolis: Univocal Publishing, 2017).

Simondon, G. (2005 [1958]) Individuation à la lumière des notions de forme et d'information. Grenoble: Millon (Individuation in Light of Notions of Form and Information. University of Minnesota Press, 2020).

Simondon, G. (2015) Culture and technics. Radical Philosophy 189: 17-23.

Stiegler, B. (1998) Technics and time, 1: The fault of epimetheus. Stanford: Stanford University Press. Timpanaro, S. (1975) Engels, materialism and 'free will.' On Materialism. London: NLB, pp. 73-133. Toscano, A. (2007) Technical culture and the limits of interaction: A note on Simondon. In J. Brouwer and A. Mulder (eds.) Interact or die! Rotterdam: Nai Publishers, pp. 198-205. 
Tosel, A. (1995) Formes de mouvement et dialectique dans la nature selon Engels. Revue Philosophique De La France Et De L'étranger 185(4): 433-462.

Virno, P. (2003) The multitude and the principle of individuation. Graduate Faculty Philosophy Journal 24(2): 133-145.

Wallimann, I. (1981) Estrangement. Marx's Conception of Human Nature and the Division of Labor. Westport-London: Greenwood Press.

Publisher's Note Springer Nature remains neutral with regard to jurisdictional claims in published maps and institutional affiliations. 